\title{
16. OXYGEN- AND CARBON-ISOTOPE VARIATIONS AND PLANKTONIC-FORAMINIFER DEPTH HABITATS, LATE CRETACEOUS TO PALEOCENE, CENTRAL PACIFIC, DEEP SEA DRILLING PROJECT SITES 463 AND $465^{1}$
}

\author{
Anne Boersma, Lamont-Doherty Geological Observatory of Columbia University, Palisades, New York \\ and \\ Nicholas J. Shackleton, University of Cambridge, Cambridge, United Kingdom
}

\section{INTRODUCTION}

The purpose of this study was to measure the carbonand oxygen-isotope ratios through the upper Cretaceous and across the Cretaceous/Tertiary boundary in the Pacific Ocean (Fig. 1). Deep Sea Drilling Project Site 465 was chosen because of the good to very good preservation of its Cretaceous faunas and a very well-preserved, 100-cm-long, earliest Tertiary "Globigerina" eugubina Zone. The longer section at Site 463 was also measured, where preservation permitted. We made reconnaissance measurements (one per planktonic zone) of the upper Cretaceous from the Turonian through the Maastrichtian. Sampling across the Cretaceous/Tertiary boundary through the early "'G." eugubina Zone. Samples were zoned according to the zonation of van Hinte (1976) for the Cretaceous, and Premoli-Silva and Bolli (1975) for the Paleocene.

Unispecific samples of size-graded planktonic foraminifers and uni- and multispecific samples of benthic foraminifers were measured. Methods of Shackleton are described in Shackleton and Opdyke (1974). We assumed that the oxygen-isotope ratio records temperature through this time, and we made a correction of $-1.00 \%$ to SMOW when converting to temperature. The most negative oxygen-isotope planktonic value is used to construct near-surface paleotemperature curves.

\section{PREVIOUS STUDIES}

Semi-continuous records of Cretaceous oxygen isotopes have been produced for Pacific nannofossils and foraminifers (Douglas and Savin, 1971, 1973, 1975), New Zealand belemnites (Stevens and Clayton, 1971), and Pacific Antarctic nannofossils and foraminifers (Margolis et al., 1977). In the Atlantic, records based on foraminifers have been produced by Saito and Van Donk (1974) and Boersma and Shackleton (1979, in press), and on European belemnites by Spaeth et al. (1971).

The Cretaceous/Tertiary boundary has been analyzed at DSDP Site 47 in the Pacific (Douglas and Savin, 1973), and at Sites 365, 152, 357, 384, 21, 20C, and on the Agulhas Plateau of the Atlantic (Boersma and Shackleton, 1979, in press; Thierstein and Berger, 1978, Saito and Van Donk, 1974).

\footnotetext{
${ }^{1}$ Initial Reports of the Deep Sea Drilling Project, Volume 62.
}

Summarizing previous isotope work, Savin (1977) reported that in general paleotemperatures are thought to begin a warming trend in the Barremian, reaching a temperature maximum for the Cretaceous in the late $\mathrm{Al}$ bian and perhaps the earliest Cenomanian; they then drop off to a temperature minimum in the later Cenomanian. Warming is again reported in the Coniacian reaching a Late Cretaceous maximum in the Santonian. In the Pacific, temperatures drop off through the Campanian and Maastrichtian to a minimum in the early Maastrichtian Gtr. tricarinata Zone, then climb slowly through the Gtr. gansseri Zone to values about $6^{\circ}$ below the late Campanian highs.

Douglas and Sliter (1966) predicted an apparent thermal gradient in the Cretaceous of $10^{\circ} \mathrm{C}$ from the Tethys to New Zealand. Douglas and Savin (1975) later reported the Early Cretaceous meridional temperature gradient to be nearly one-third of its value in the Pacific today.

\section{OXYGEN ISOTOPES}

\section{Site 463}

We measured Turonian ( $G$. helvetica Zone) through Maastrichtian (A. mayaroensis Zone) unispecific planktonics, but multispecific benthic samples at Site 463 in the Mid-Pacific Mountains (Fig. 2; Tables 1 and 2). Planktonic oxygen-isotope values become slightly heavier (more positive) from the $M$. renzi-M. sigali Zone into the M. sigali-G. concavata Zone.

Lighter near-surface values of the Gtr. calcarata Zone become heavier again in the early Maastrichtian Gtr. scutilla Zone, and remain near these values through the remainder of the Maastrichtian.

The relatively light benthic values of the $M$. helvetica Zone through the Gtr. scutilla Zone of the Maastrichtian become heavier in the Gtr. gansseri Zone and continue so into the A. mayaroensis Zone of the late Maastrichtian. No latest Cretaceous sediments were recovered at this site.

\section{Site 465}

Only samples from the Gtr. elevata through $A$. mayaroensis Zones were well-enough preserved to measure (Fig. 2; Table 3). Planktonic values become heavier from the Campanian into the Maastrichtian; heaviest values occur in the Gtr. scutilla Zone and continue into the Gtr. gansseri Zone. Oxygen-isotope ratios become 


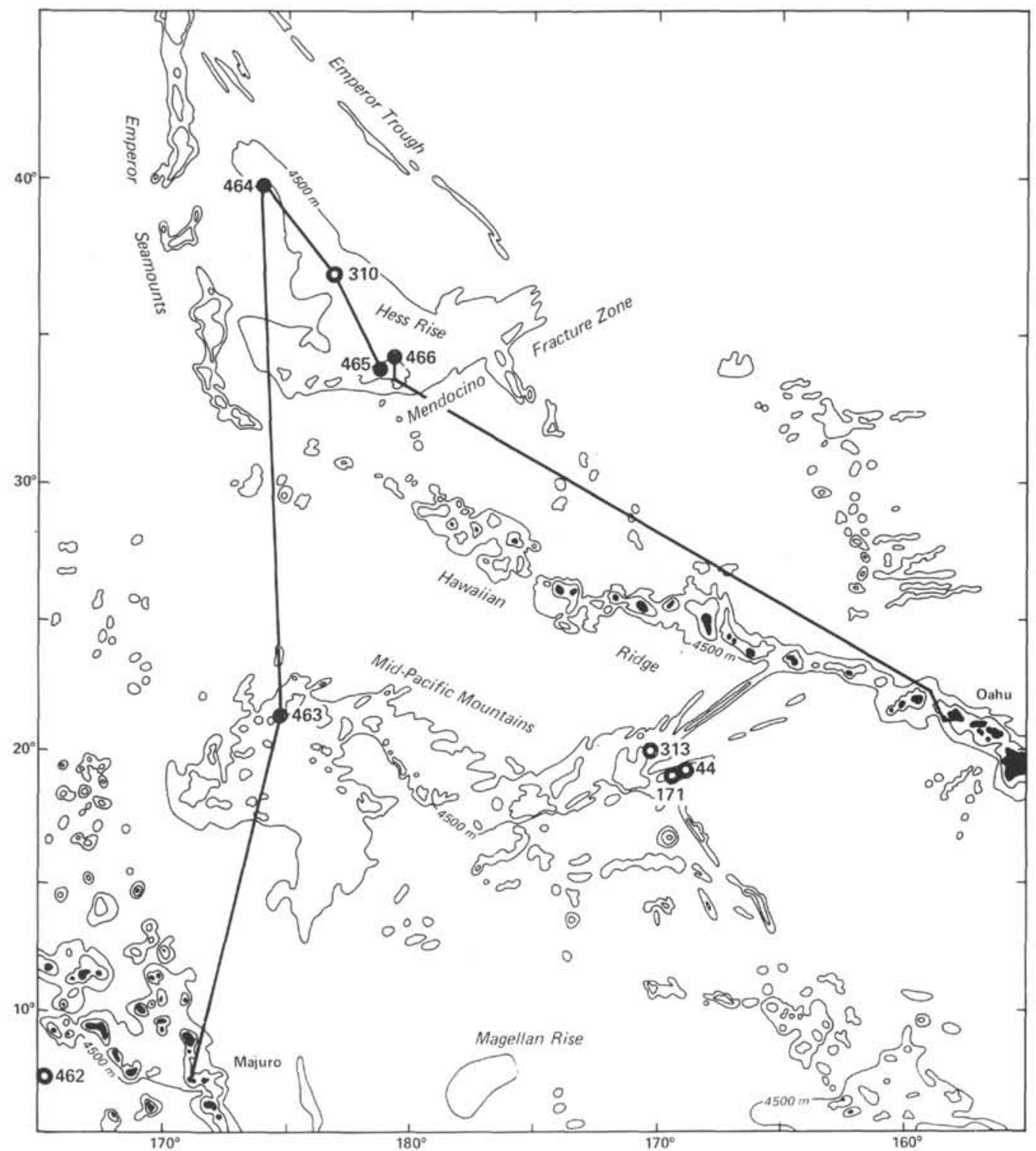

Figure 1. Location of the Leg 62 drill sites in the central Pacific Ocean.

slightly lighter through the remainder of the Maastrichtian.

Benthic oxygen-isotope values fluctuate from +0.2 to $-0.4 \%$ in the Campanian, but become significantly heavier in the Gtr. scutilla Zone. Slightly lighter values obtain in the later Maastrichtian Gtr. gansseri through A. mayaroensis Zones. There is a slight, but significant excursion to heavier values near the top of the $A$. mayaroensis Zone.

\section{The Cretaceous/Tertiary Boundary}

Measurements across the Cretaceous/Tertiary boundary at Site 465 (Table 4; Fig. 3) are based on the lightest oxygen-isotope planktonic species Psg. excolata below and $G$. cretacea above the boundary, because the same species could not be measured through the boundary interval. Planktonic-foraminifer oxygen-isotope values become $0.6 \%$ across the boundary, and remain at slightly heavier values through the " $G$." eugubina
Zone, fluctuations of 0.1 to $0.4 \%$ being common throughout the sequence.

Benthic values are based on unispecific samples of Bulimina sp. throughout the sequence. Despite the marked size difference in buliminids across the boundary, similar oxygen-isotope ratios are measured. Benthic values become slightly lighter above the boundary, but return to heavier values higher in the " $G$." eugubina Zone. Pronounced lightening of benthic values is registered in Zone P1 of the Danian.

\section{CARBON ISOTOPES}

\section{Site $\mathbf{4 6 3}$}

Planktonic-foraminifer $\delta^{13} \mathrm{C}$ values drop by $0.6 \%$ (Table 2; Fig. 4), from the $M$. helvetica Zone into the $M$. renzi-M. sigali Zone and $M$. sigali-Gtr. concavata Zones. A lightening trend continues through the Campanian and across the boundary into the Maastrichtian. 

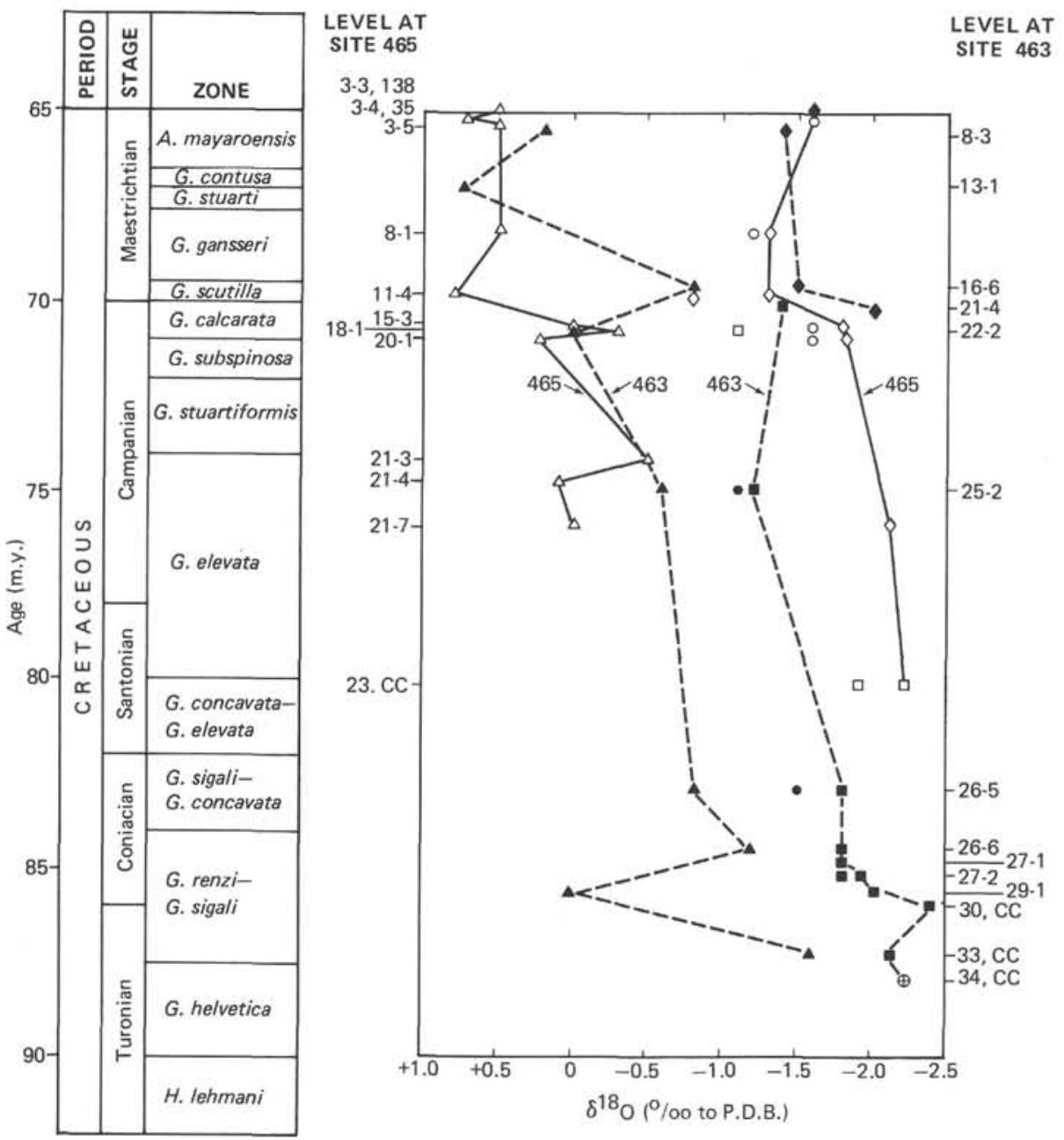

Figure 2. Oxygen-isotope records from Sites 463 and 465, central Pacific. The time-scale follows van Hinte (1976). The continuous line represents the record at Site 465 , and the dashed line the record at Site 463. Foraminifer values from Tables 2 and 3 are represented by the following symbols: diamond, Pseudoguembelina; square, Globotruncana; triangle, benthic foraminifers; circle, Rugoglobigerina; crossed circle, Whiteinella.

Table 1. Location and depth of Atlantic and Pacific ocean sites discussed in this report.

\begin{tabular}{|c|c|c|c|}
\hline Site & Latitude & Longitude & $\begin{array}{l}\text { Water } \\
\text { Depth } \\
\text { (m) }\end{array}$ \\
\hline 463 & $21^{\circ} 21^{\prime} \mathrm{N}$ & $174^{\circ} 40^{\prime} \mathrm{E}$ & 2525 \\
\hline $465 \mathrm{~A}$ & $33^{\circ} 49^{\prime} \mathrm{N}$ & $178^{\circ} 55^{\prime} \mathrm{E}$ & 2161 \\
\hline 384 & $40^{\circ} 21^{\prime} \mathrm{N}$ & $51^{\circ} 39^{\prime} \mathrm{W}$ & 3909 \\
\hline 356 & $28^{\circ} 17^{\prime} \mathrm{S}$ & $41^{\circ} 05^{\prime} \mathrm{W}$ & 3175 \\
\hline 152 & $15^{\circ} 52^{\prime} \mathrm{N}$ & $74^{\circ} 36^{\prime} \mathrm{W}$ & 3899 \\
\hline 47.2 & $32^{\circ} 26^{\prime} \mathrm{N}$ & $157^{\circ} 42^{\prime} \mathrm{E}$ & 2689 \\
\hline 357 & $30^{\circ} 00^{\prime} \mathrm{S}$ & $35^{\circ} 33^{\prime} \mathrm{W}$ & 2086 \\
\hline $\begin{array}{l}\text { Agulhas Plateau, } \\
\text { V16-56 }\end{array}$ & $41^{\circ} 21^{\prime} \mathrm{S}$ & $26^{\circ} 38^{\prime} \mathrm{E}$ & 1665 \\
\hline
\end{tabular}

The most negative value occurs in the earliest Maastrichtian, in the Gtr. scutilla Zone, followed by increasingly positive values through the course of the Maastrichtian.
Benthic values are based on mixed samples. Values are heavier in the Turonian, lighter through the Campanian, and heavier again in the Maastrichtian.

\section{Site $\mathbf{4 6 5}$}

Planktonic foraminifer $\delta^{13} \mathrm{C}$ values become slightly lighter (Fig. 4; Table 3) from the Gtr. concavata-Gtr. elevata Zone into the Gtr. elevata Zone, of early Campanian age. Heavier values characterize the course of the Campanian and Maastrichtian, but drop off slightly just below the boundary with the Tertiary. The trend among benthic foraminifers approximately parallels that of the planktonics. The surface-to-bottom carbonisotope gradient at the end of the Maastrichtian is approximately $1 \%$.

\section{The Cretaceous/Tertiary Boundary}

There is a marked drop in planktonic-foraminifer carbon-isotope ratios by $1.2 \%$ across the Cretaceous/ Tertiary boundary. Benthic species show no drop, but 
Table 2. Oxygen- and carbon-isotope values from planktonic and benthonic foraminifers from Site 463.

\begin{tabular}{|c|c|c|c|}
\hline Level & Species & $\delta^{18} \mathrm{O}$ & $\delta^{13} \mathrm{C}$ \\
\hline \multirow[t]{2}{*}{$463-8-3,37 \mathrm{~cm}$} & P. excolata & -1.43 & +2.32 \\
\hline & N. truempyi & +0.22 & +0.91 \\
\hline $463-13-1,48 \mathrm{~cm}$ & Benthics & +0.77 & +0.39 \\
\hline \multirow[t]{2}{*}{$463-16-6,47 \mathrm{~cm}$} & P. excolata/costulata & -1.59 & +1.76 \\
\hline & Benthics & -0.82 & +0.40 \\
\hline \multirow[t]{5}{*}{$463-21-4,14 \mathrm{~cm}$} & P. costulata & -2.09 & +2.03 \\
\hline & Gtr. calcarata & -1.46 & +1.86 \\
\hline & Gtr. elevata & -1.43 & +2.15 \\
\hline & Gtr. subspinosa & -1.31 & +2.08 \\
\hline & Benthics & -0.19 & +1.10 \\
\hline $463-22-2,32 \mathrm{~cm}$ & Benthics & +0.01 & +0.63 \\
\hline $463-23-1,50 \mathrm{~cm}$ & P. costulata & -2.05 & +2.06 \\
\hline \multirow[t]{4}{*}{$463-25-2,69 \mathrm{~cm}$} & Gtr. fornicata & -1.29 & +2.01 \\
\hline & Gtr. elevata & -1.26 & +2.18 \\
\hline & R. rugosa & -1.13 & +2.30 \\
\hline & Nodosaria sp. & -0.63 & +0.07 \\
\hline \multirow[t]{4}{*}{$463-26-5,84 \mathrm{~cm}$} & Gtr. carinata & -1.96 & +1.89 \\
\hline & Gtr. fornicata & -1.83 & +2.38 \\
\hline & R. rugosa & -1.53 & +2.34 \\
\hline & Benthics & -0.80 & +1.18 \\
\hline \multirow[t]{3}{*}{$463-26-6,119 \mathrm{~cm}$} & Gtr. fornicata & -1.87 & +2.17 \\
\hline & M. renzi & -1.70 & +2.14 \\
\hline & Benthics & -1.22 & +0.22 \\
\hline \multirow[t]{2}{*}{$463-27-1,107 \mathrm{~cm}$} & Gtr. fornicata $(425-355 \mu)$ & -1.88 & +1.88 \\
\hline & Gtr. fornicata $(355-300 \mu)$ & -1.92 & +1.96 \\
\hline \multirow[t]{4}{*}{$463-27-2,16 \mathrm{~cm}$} & Gtr. concavata $(425-355 \mu)$ & -1.98 & +1.80 \\
\hline & Gtr. concavata $(355-300 \mu)$ & -1.94 & +1.80 \\
\hline & Gtr. concavata $(300-250 \mu)$ & -1.97 & +1.82 \\
\hline & Gtr. fornicata $(425-355 \mu)$ & -1.89 & +1.92 \\
\hline \multirow[t]{2}{*}{$463-29-1,29 \mathrm{~cm}$} & Gtr. fornicata & -2.05 & +1.97 \\
\hline & Nuttalides sp. & +0.05 & +1.03 \\
\hline $463-30, \mathrm{CC}$ & Gtr. fornicata & -2.05 & +1.97 \\
\hline \multirow[t]{2}{*}{$463-33, \mathrm{CC}$} & $M$. helvetica $(425-355 \mu)$ & -2.12 & +2.71 \\
\hline & Benthics & -1.62 & +1.07 \\
\hline $463-34, C C$ & Whiteinella alpina $(425-355 \mu)$ & -2.22 & +2.87 \\
\hline
\end{tabular}

register identical values across the boundary an through the ' $G$." eugubina Zone. The resultant carbon-isotope gradient between planktonic and benthic foraminifers in the "G." eugubina Zone is negative. Planktonic values remain light through the course of the " $G$." eugubina Zone, showing little fluctuation. Both planktonic and benthic values become significantly lighter in Zone P1.

\section{DISCUSSION}

According to the rotational plate reconstruction model of Lancelot and Larson (1975), Site 463 was located in the central subtropical belt of the Pacific through the Late Cretaceous, until it crossed the equator at approximately 65 to $70 \mathrm{~m}$.y. ago (Fig. 5). Site 465 , slightly to the north, crossed the equator in the Turonian and moved through the northwest subtropical belt through the course of the Cretaceous and early Tertiary. It was located near $15^{\circ} \mathrm{N}$ at the Cretaceous/Tertiary boundary.

\section{Turonian}

Near-surface paleotemperatures at Site 463 increase slightly from the Turonian to the Santonian. The Turonian benthic oxygen-isotope value appears anomalously high and suggests recrystallization alteration of oxygenisotope values, possibly in the planktonics as well. The Turonian carbon-isotope gradient from surface to bottom is strong, implying that samples have retained their
Table 3. Oxygen- and carbon-isotope data for planktonic and benthic foraminifers from Site 465 .

\begin{tabular}{|c|c|c|c|}
\hline Level & Species & $\delta^{18} \mathrm{O}$ & $\delta^{13} \mathrm{C}$ \\
\hline \multirow[t]{2}{*}{$465-3-3,138 \mathrm{~cm}$} & P. excolata & -1.65 & +2.74 \\
\hline & Bulimina & +0.59 & +1.63 \\
\hline \multirow[t]{4}{*}{$465-3-3,146 \mathrm{~cm}$} & P. excolata & -1.16 & +2.97 \\
\hline & N. truempyi & +0.34 & +1.35 \\
\hline & Bulimina & +0.70 & +1.72 \\
\hline & Gavelinella & +0.04 & +1.58 \\
\hline \multirow[t]{4}{*}{$465-3-4,4 \mathrm{~cm}$} & Rugoglobigerina rotundata & -1.65 & +3.19 \\
\hline & R. rugosa & -1.63 & +3.01 \\
\hline & N. truempyi & -0.08 & +1.25 \\
\hline & Bulimina & +0.79 & +1.69 \\
\hline \multirow[t]{2}{*}{$465-3-4,33 \mathrm{~cm}$} & P. excolata & -1.42 & +2.67 \\
\hline & Bulimina & +0.85 & +1.61 \\
\hline \multirow[t]{2}{*}{$465-3-4,47 \mathrm{~cm}$} & R. rotundata & -1.33 & +2.89 \\
\hline & Bulimina & +0.79 & +1.77 \\
\hline \multirow[t]{3}{*}{$465-3-4,75 \mathrm{~cm}$} & P. excolata (short) & -1.33 & +2.35 \\
\hline & P. excolata (long) & -1.34 & +2.65 \\
\hline & Bulimina & +0.74 & +1.59 \\
\hline $465-3-5,23 \mathrm{~cm}$ & Bulimina & +0.50 & +1.21 \\
\hline \multirow[t]{3}{*}{$465-8-1,21 \mathrm{~cm}$} & P. excolata & -1.31 & +2.56 \\
\hline & R. rugosa & -1.27 & +2.83 \\
\hline & Bulimina & +0.56 & +1.36 \\
\hline \multirow[t]{3}{*}{$465-11-4$} & P. excolata & -1.33 & +2.57 \\
\hline & P. globulosa & -0.88 & +2.29 \\
\hline & Nuttalides, Bulimina & +0.89 & +0.64 \\
\hline $465-15-3,29 \mathrm{~cm}$ & N. truempyi & -0.05 & +0.87 \\
\hline \multirow{8}{*}{$465-18-1,40 \mathrm{~cm}$} & P. costulata & -1.81 & +2.09 \\
\hline & R. rugosa & -1.69 & +2.52 \\
\hline & P. elegans & -1.60 & +3.08 \\
\hline & Gtr. subspinosa & -1.25 & +2.32 \\
\hline & Gtr. calcarata & -1.27 & +2.33 \\
\hline & Gtr. elevata & -1.16 & +2.42 \\
\hline & Gtr. fornicata & -1.17 & +2.54 \\
\hline & N. truempyi & -0.33 & +0.70 \\
\hline \multirow[t]{2}{*}{$465-20-1,70 \mathrm{~cm}$} & N. truempyi & +0.25 & +0.84 \\
\hline & Bulimina & +0.65 & +1.44 \\
\hline $465-21-3,132 \mathrm{~cm}$ & N. truempyi & -0.59 & +1.22 \\
\hline $465-21-4,14 \mathrm{~cm}$ & Benthics & -0.19 & +1.10 \\
\hline \multirow{2}{*}{$465-21-17,14 \mathrm{~cm}$} & P. costulata & -2.12 & +1.89 \\
\hline & N. truempyi & -0.04 & +0.79 \\
\hline \multirow[t]{3}{*}{$465-23, \mathrm{CC}$} & Gtr. concavata & -2.25 & +2.19 \\
\hline & Gtr. carinata & -1.93 & +2.52 \\
\hline & Gtr. fornicata & -1.90 & +2.38 \\
\hline
\end{tabular}

Table 4. Oxygen- and carbon-isotope values for planktonic and benthic foraminifers from the early Tertiary at Site 465 .

\begin{tabular}{clll}
\hline \multicolumn{1}{c}{ Level } & \multicolumn{1}{c}{ Species } & $\delta^{18} \mathrm{O}$ & ${ }^{13} \mathrm{C}$ \\
\hline & “G.' eugubina Zone \\
$465-3-3,138 \mathrm{~cm}$ & G. cretacea & -1.03 & +1.55 \\
& Bulimina & +0.78 & +1.70 \\
$465-3-3,130 \mathrm{~cm}$ & G. cretacea & -1.44 & +1.17 \\
& Bulimina & +0.24 & +1.46 \\
$465-3-3,120 \mathrm{~cm}$ & G. cretacea & -1.25 & +1.36 \\
& Bulimina & -0.17 & +1.40 \\
$465-3-3,111 \mathrm{~cm}$ & G. cretacea & -1.30 & +1.27 \\
& Bulimina & +1.04 & +1.75 \\
$465-3-3,40 \mathrm{~cm}$ & G. cretacea & -1.11 & +1.34 \\
& Bulimina & +0.66 & +1.79 \\
$465-3-3,20 \mathrm{~cm}$ & G. cretacea & -1.14 & +1.24 \\
& Bulimina & +0.88 & +1.82 \\
& $\quad$ Zone P1 & & \\
$465-3-1,20 \mathrm{~cm}$ & G. cretacea & -1.06 & +0.92 \\
& N. truempyi & -0.23 & +1.37 \\
\hline
\end{tabular}



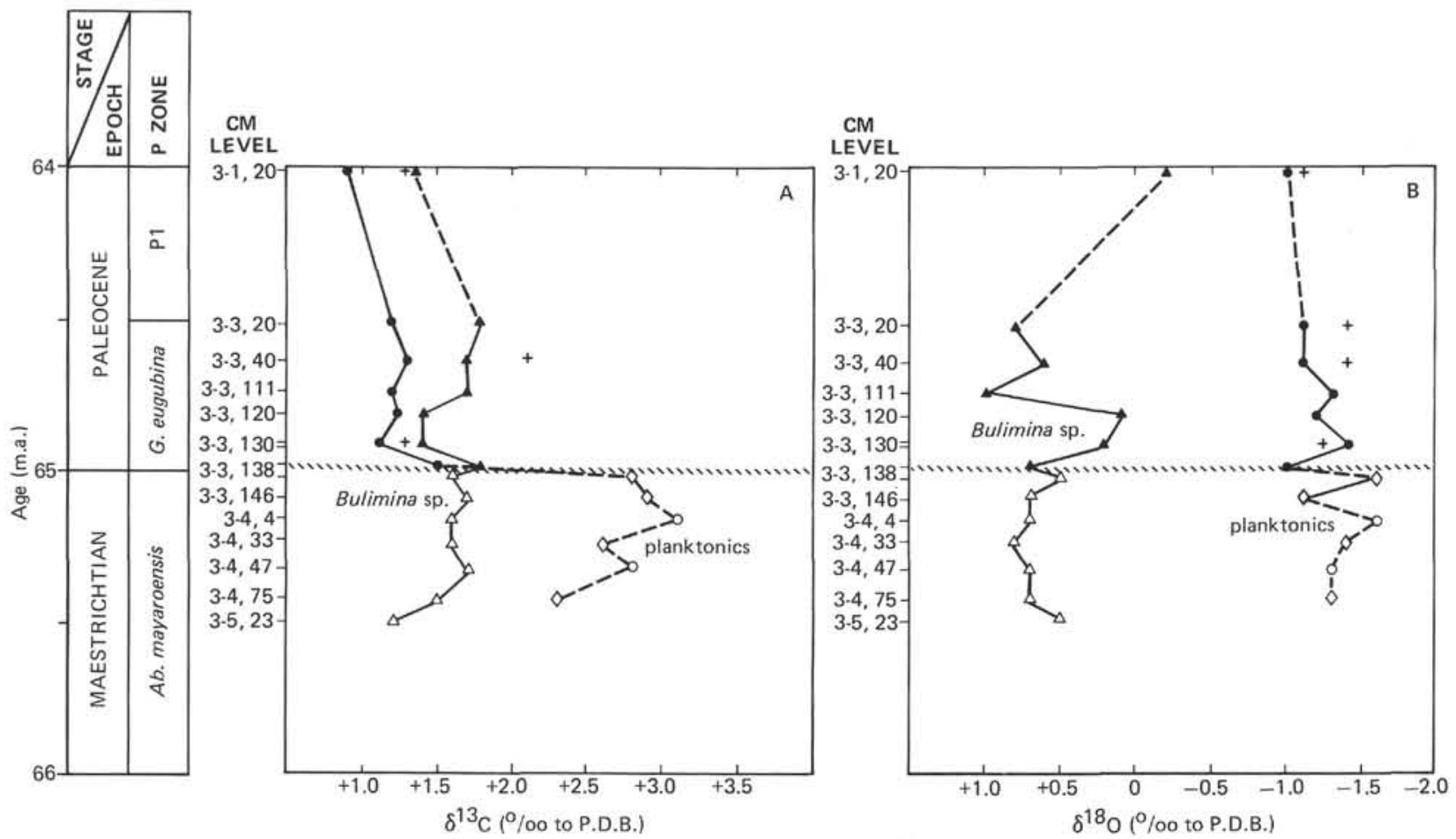

Figure 3. Oxygen- and carbon-isotope records across the Cretaceous/Tertiary Boundary and through the "G." eugubina Zone at Hole 465A. Time scale follows Premoli Silva and Bolli (1975). Foraminifera are represented by the following symbols: triangle (open), Cretaceous Bulimina; triangle (blacked), Tertiary Bulimina; open circle, Rugoglobigerina; black circle, Guembelitria; diamond, Pseudoguembelina; and cross, Chiloquembelina. Data are from Table 4.

carbon-isotope signal and(or) that nutrient gradients were high.

\section{Coniacian}

The Late Cretaceous temperature maximum near $21^{\circ} \mathrm{C}$ is registered at this time; benthic values are also high, near 15 to $17^{\circ} \mathrm{C}$. These values are within the range published for belemnites (Sliter, 1976). The value for $N$. truempyi, $12^{\circ} \mathrm{C}$ (463-29-1), is closer to later Cretaceous Pacific and Atlantic intermediate-depth bottom temperatures and appears more reliable. The thermal gradient from surface to bottom (using $N$. truempyi) was near $9^{\circ} \mathrm{C}$.

Carbon-isotope gradients vary according to the composition of the benthic samples; values average near $1.0 \%$, which is slightly less than the gradient in today's ocean.

\section{Santonian}

Only near-surface temperature (near $21^{\circ} \mathrm{C}$ ) was measured at Site 465 .

\section{Campanian}

Through the early Campanian, near-surface paleotemperatures at Site 465 are $3^{\circ} \mathrm{C}$ higher than those at Site 463. This may result from using globotruncanids (more oxygen-isotope positive in depth stratification studies) at Site 463, but Pseudoguembelina, usually the most oxygen-isotope negative Cretaceous planktonic foraminifer, at Site 465. In the late Campanian, Pseudoguembelina was measured at both sites; and this pro- duced a $3^{\circ} \mathrm{C}$ temperature differential and near-surface temperature highs of $21^{\circ} \mathrm{C}$ at Site 463 , a value equivalent to the Coniacian temperature maximum.

Carbon-isotope gradients are greater than in the Coniacian, averaging near $1.5 \%$ by late Campanian; this value approximates that of the ocean today.

\section{Maastrichtian}

There is a drop in near-surface and bottom temperature in the early Maastrichtian Gtr. scutilla Zone (= Gtr. tricarinata Zone of other authors). The very high benthic value at Site $463(16-6)$ is considered anomalous. Near-surface temperatures at Site 465 increase slightly through the late Maastrichtian, achieving values slightly below the late Campanian high by the end of the $A$. mayaroensis Zone. There is little change in near-surface temperature at Site 463.

Bottom temperatures at Site 465 are all based on Bulimina sp. From the early Maastrichtian low of $9^{\circ} \mathrm{C}$, temperatures rise slightly through the Maastrichtian and demonstrate the characteristic positive excursion just below the Cretaceous/Tertiary boundary which is found at other Cretaceous and Atlantic sites.

Carbon-isotope gradients at both Sites 463 and 465 are near $1.5 \%$. Near-surface and benthic values are both lower at Site 463, which was situated near the equator at this time.

\section{Cretaceous/Tertiary Boundary}

Across the Cretaceous/Tertiary boundary, there is no temperature change recorded by benthic foraminifers, 

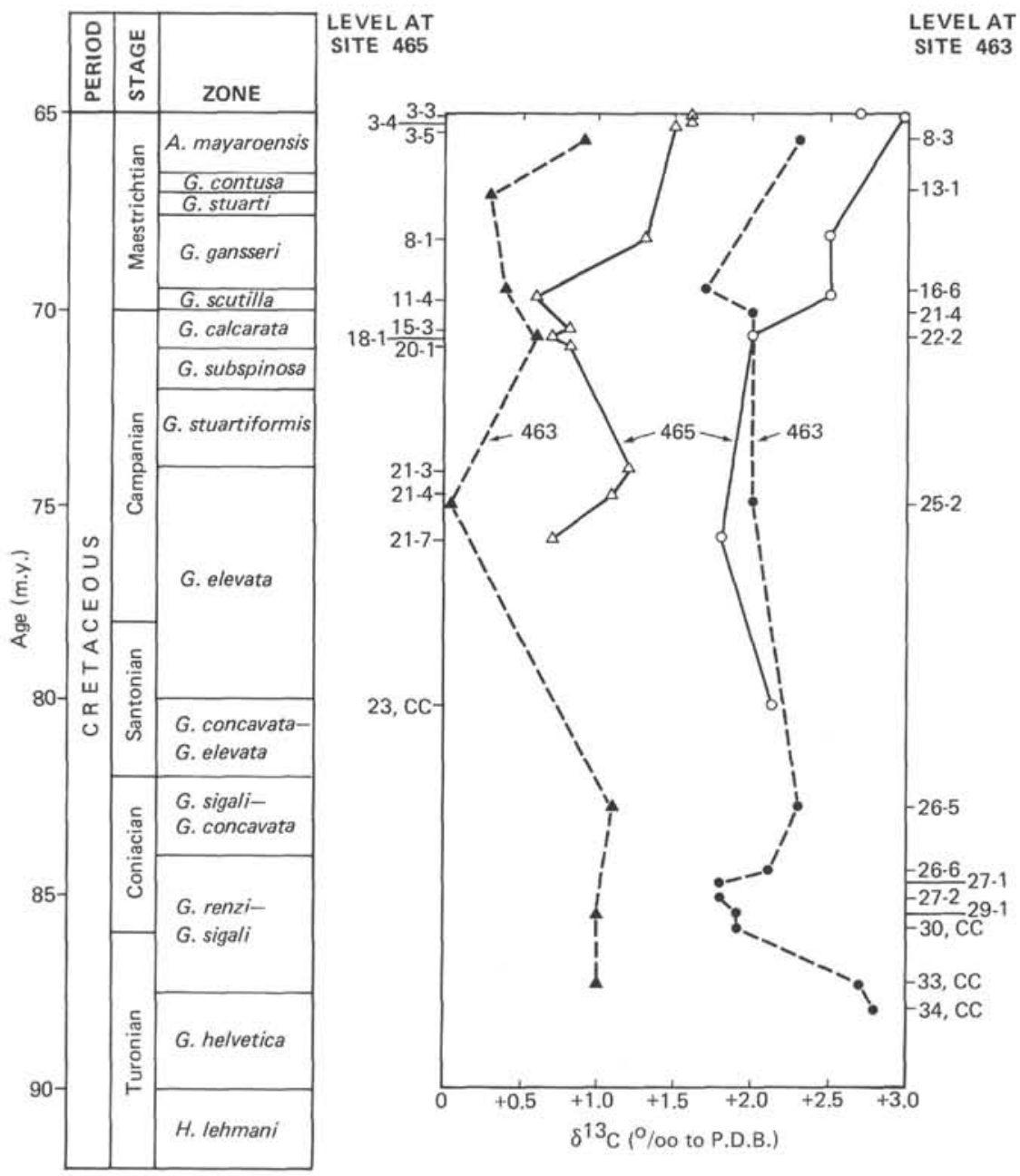

Figure 4. Carbon-isotope records of benthic foraminifers and the lightest oxygen-isotope planktonic-foraminifer through the Late Cretaceous at Sites 463 and 465. Dashed line indicates the record for Site 463 , solid line Site 465 . Triangles represent benthic analyses; circles, planktonic foraminifers. Data are from Tables 2 and 3. Time-scale follows van Hinte (1976).

but a drop in near-surface temperature from 19 to $16^{\circ} \mathrm{C}$. At Site 47 on Shatsky Rise, Douglas and Savin (1971) recorded a near-surface temperature rise from 15 to $16^{\circ} \mathrm{C}$, based on mixed planktonic foraminifers. In the Atlantic at Site 356, planktonic species indicate a temperature increase, and at Site 384 a slight temperature decrease (Boersma and Shackleton, 1977, 1979, in press). Despite the contradictory results, it is apparent that there is very little temperature change across the Cretaceous/Tertiary boundary.

There is, however, a substantial decrease in carbonisotope gradients measured at all Atlantic and Pacific sites across the Cretaceous/Tertiary boundary. Gradients of near $1.5 \%$ in the Cretaceous are reduced to near zero in the earliest Tertiary at all sites.

In the Atlantic, this decrease is caused by decreased surface carbon-isotope values, as benthic values remain relatively constant. In the Pacific at Site 465 , this decrease is also caused by a $1 \%$ decrease in planktonic carbon-isotope values.
Broecker (1974) demonstrated that today and across the glacial/Holocene transition the surface-to-bottom carbon-isotope gradient can be related to carbon utilization, and hence productivity, at the ocean surface. Today, assuming a photosynthetic fractionation factor of $-25 \%, 10 \%$ utilization of available $\Sigma \mathrm{CO}_{2}$ for organiccarbon production is required to produce a surface-tobottom carbon-isotope gradient near $1.5 \%$. Increased productivity, hence increased carbon utilization, will result in an increased carbon-isotope gradient, all other factors being equal.

The decrease in the Cretaceous to early Tertiary carbon-isotope gradient from $1.5 \%$ to 0 represents a decrease in $\mathrm{\Sigma CO}_{2}$ utilization for organic-carbon production to near 0 , or below our ability to resolve.

We believe that the greatly reduced productivity and carbon utilization of the early Tertiary is the reflection of the Cretaceous/Tertiary boundary "catastrophe," which occurred on a time scale below our ability to resolve with isotope analysis. 


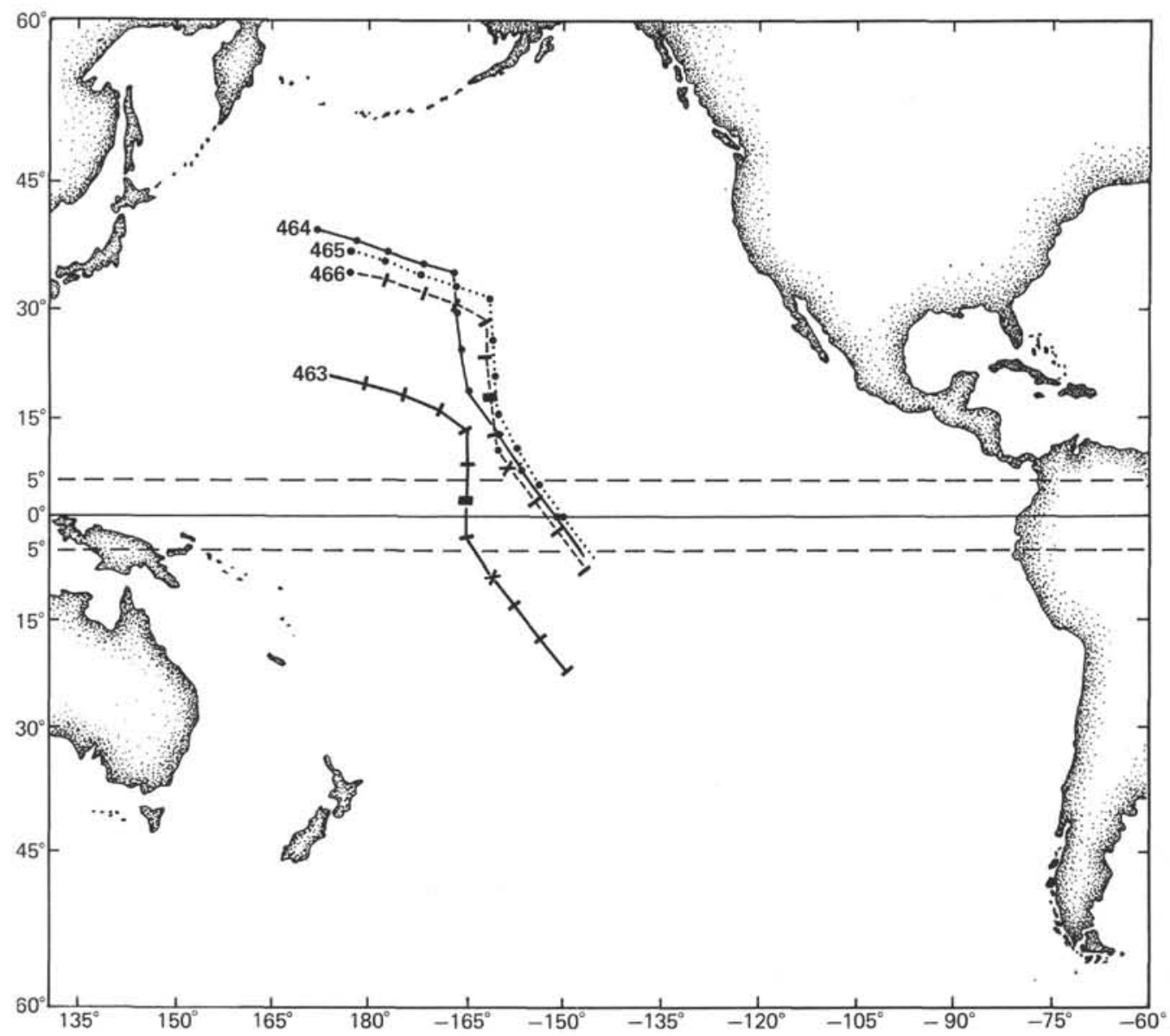

Figure 5. Paleolatitudinal reconstructions of the positions of DSDP Sites 463 and 465 in the central Pacific, according to the rotational reconstruction model of Lancelot and Larson (1975). Bars along the site paths represent increments of $10 \mathrm{~m} . \mathrm{y}$. The solid bar indicates the position of each site at $60 \mathrm{~m} . \mathrm{y}$. ago, and the cross the position at $80 \mathrm{~m} . \mathrm{y}$. ago. Paths for Sites 464 and 466 are also shown.

\section{Early Tertiary “'G.” eugubina Zone}

Following the slight near-surface temperature drop across the Cretaceous/Tertiary boundary, temperatures rise slightly in the "'G.' eugubina Zone, but decrease again in the later "G.' eugubina Zone and into Zone P1. At Sites 356 and 384 in the Atlantic, only a slight decrease in temperature through the 'G.' eugubina Zone is recorded (Boersma and Shackleton, 1979). Nearsurface-temperature estimates are lower at these sites into Zone P1, as at Site 465. Surface-to-bottom (near $2000 \mathrm{~m}$ ) temperature gradients fluctuate from 5 to $7^{\circ} \mathrm{C}$ through this time period, in contrast to today's Pacific subtropical vertical temperature range over $17^{\circ} \mathrm{C}$ from the surface to near 2000 meters.

The minimal-to-negative carbon-isotope gradients continue through the "G.' eugubina Zone into Zone P1 at Site 465, as well as in the Atlantic, suggesting low surface productivity in both oceans throughout this time.

\section{Geographic Distribution of Paleotemperature Data}

The accumulated data on late Campanian and late Maastrichtian oxygen isotopes and estimated paleotemperatures based on nannofossils and planktonic foraminifers are listed in Tables 5 and 6 and shown in
Table 5. Oxygen-isotope values and related estimated paleotemperatures from planktonic and benthic foraminifers of late Maastrichtian age at Pacific and Atlantic DSDP sites. Nannofossil data are from Douglas and Savin $(1971,1975)$, and information on Site 21 is from Saito and Van Donk (1974).

\begin{tabular}{llcc}
\hline \multicolumn{1}{c}{ Site/Level } & \multicolumn{1}{c}{ Species } & $\delta^{18} \mathrm{O}$ & $\begin{array}{r}\text { Estimated Temperature } \\
\left({ }^{\circ} \mathrm{C}\right)\end{array}$ \\
\hline $152-15-2,86 \mathrm{~cm}$ & Psg. excolata & -1.91 & 20 \\
& Benthics & -0.02 & 12 \\
V16-56, $168 \mathrm{~cm}$ & R. rugosa & -0.85 & 15 \\
& Gavelinella sp. & +0.27 & 13 \\
$357-31-1,17 \mathrm{~cm}$ & Psg. excolata & -1.14 & 17 \\
& Benthics & -0.43 & 14 \\
$356-29-3,50 \mathrm{~cm}$ & Psg. excolata & -1.89 & 20 \\
& Gavelinella beccariformis & -1.08 & 16 \\
$384-13-4,135 \mathrm{~cm}$ & Psg. excolata & -0.92 & 16 \\
& Benthics & +0.18 & 12 \\
$463-8-3,37 \mathrm{~cm}$ & Psg. excolata & -1.43 & 18 \\
& N. truempyi & +0.22 & 11 \\
$465-3-4,33 \mathrm{~cm}$ & Psg. excolata & -1.42 & 18 \\
& Bulimina & +0.85 & 9 \\
$21-3, \mathrm{CC}$ & Gtr. contusa & -0.73 & 15 \\
& Benthics & +1.15 & 8 \\
$171-10-1,2 \mathrm{~cm}$ & Planktonics & -2.02 & 21 \\
$327 \mathrm{~A}-10-2,53 \mathrm{~cm}$ & R. rugosa & -0.77 & 15 \\
$167-41, \mathrm{CC}$ & Nannofossils & -0.96 & 16 \\
$310 \mathrm{~A}-1, \mathrm{CC}$ & Nannofossils & -0.76 & 15 \\
$47-12-1,5 \mathrm{~cm}$ & Nannofossils & -0.44 & 14 \\
$12, \mathrm{CC}$ & Planktonics & -0.63 & 15 \\
\hline
\end{tabular}


Table 6. Oxygen-isotope values and related paleotemperatures from planktonic and benthic microfossils of late Campanian age in the Pacific and Atlantic Oceans. Data from Sites 167, 171, and 305 are taken from Douglas and Savin $(1973,1975)$; Site 21 data are from Saito and Van Donk (1974).

\begin{tabular}{llcc}
\hline \multicolumn{1}{c}{ Site/Level } & \multicolumn{1}{c}{ Species } & $\delta^{18} \mathrm{O}$ & $\begin{array}{c}\text { Estimated Temperature } \\
\left({ }^{\circ} \mathrm{C}\right)\end{array}$ \\
\hline $356-33-2,120 \mathrm{~cm}$ & R. rugosa & -4.04 & 35 \\
$465 \mathrm{~A}-18-1,40 \mathrm{~cm}$ & Psg. costulata & -1.81 & 20 \\
& N. truempyi & -0.33 & 13 \\
$463-21-4,14 \mathrm{~cm}$ & Psg. costulata & -2.09 & 21 \\
& Benthics & -0.19 & 13 \\
$21-6, \mathrm{CC}$ & Gtr. fornicata & -1.60 & 19 \\
& Benthics & -0.14 & 13 \\
$171-20, \mathrm{CC}$ & Planktonics & -1.32 & 18 \\
$167-51, \mathrm{CC}$ & Bulk & -1.23 & 17 \\
& Nannofossils & -1.56 & 19 \\
$305-21, \mathrm{CC}$ & Nannofossils & -1.14 & 17 \\
& Benthics & -0.37 & 13 \\
\hline
\end{tabular}

Figures 6 and 7. The few data for the late Campanian indicate similar paleotemperatures in the middle-latitude South Atlantic and in the central subtropical and equatorial Pacific. The $31^{\circ} \mathrm{C}$ value at Site 365 is probably the result of recrystallization, which was evident on fossils of the Gtr. calcarata Zone at this site.

Late Maastrichtian values were slightly cooler both in the South Atlantic and subtropical Pacific. Temperatures near $15^{\circ} \mathrm{C}$ in the subtropical Pacific were equivalent to those at high middle latitudes in the northern and southern Atlantic.

Thermal gradients from the equator to approximately $45^{\circ} \mathrm{S}$ in the Atlantic were only $5^{\circ} \mathrm{C}$. In the equa- torial Pacific to Antarctic, temperature gradients reached $9^{\circ} \mathrm{C}$. East-west gradients in the Atlantic, from Site 356 on the Brazil margin to Site 21 on the eastern leg of the Rio Grande Rise, were also $5^{\circ} \mathrm{C}$. It is conceivable that in the Late Cretaceous, as in the early Tertiary, east-west gradients were more pronounced than today's, while north-south gradients were markedly lower than today's.

\section{Vertical Stratification of Planktonic Foraminifers}

By measuring the oxygen- and carbon-isotope values of all or most species in a sample, we can derive a picture of their relative ordering or vertical stratification according to temperature. Interpretations of species' relative depth habitats can be erroneous because of sizedependent isotopic fractionation, disequilibrium precipitation by some species, and differential-preservation effects. For extinct species, it is difficult to assess these factors.

Analyses of Cretaceous species in different size fractions were made by Douglas and Savin (1979), and on material from Site 463 (Table 2). Douglas and Savin concluded that correlation of isotopic value and size change was significant in size ranges below $150 \mu \mathrm{m}$. Our data show little isotopic variation with size in the range 425 to $250 \mu \mathrm{m}$, but gigantic specimens of Gtr. contusa from North Atlantic Site 384 gave oxygen-isotope values 0.2 to $0.4 \%$ heavier than normal-sized individuals.

Disequilibrium precipitation and(or) post-depositional alteration of oxygen-isotope values can be tested in two ways: (1) In multiple analyses at many sites, some species show consistently random ordering relative to other

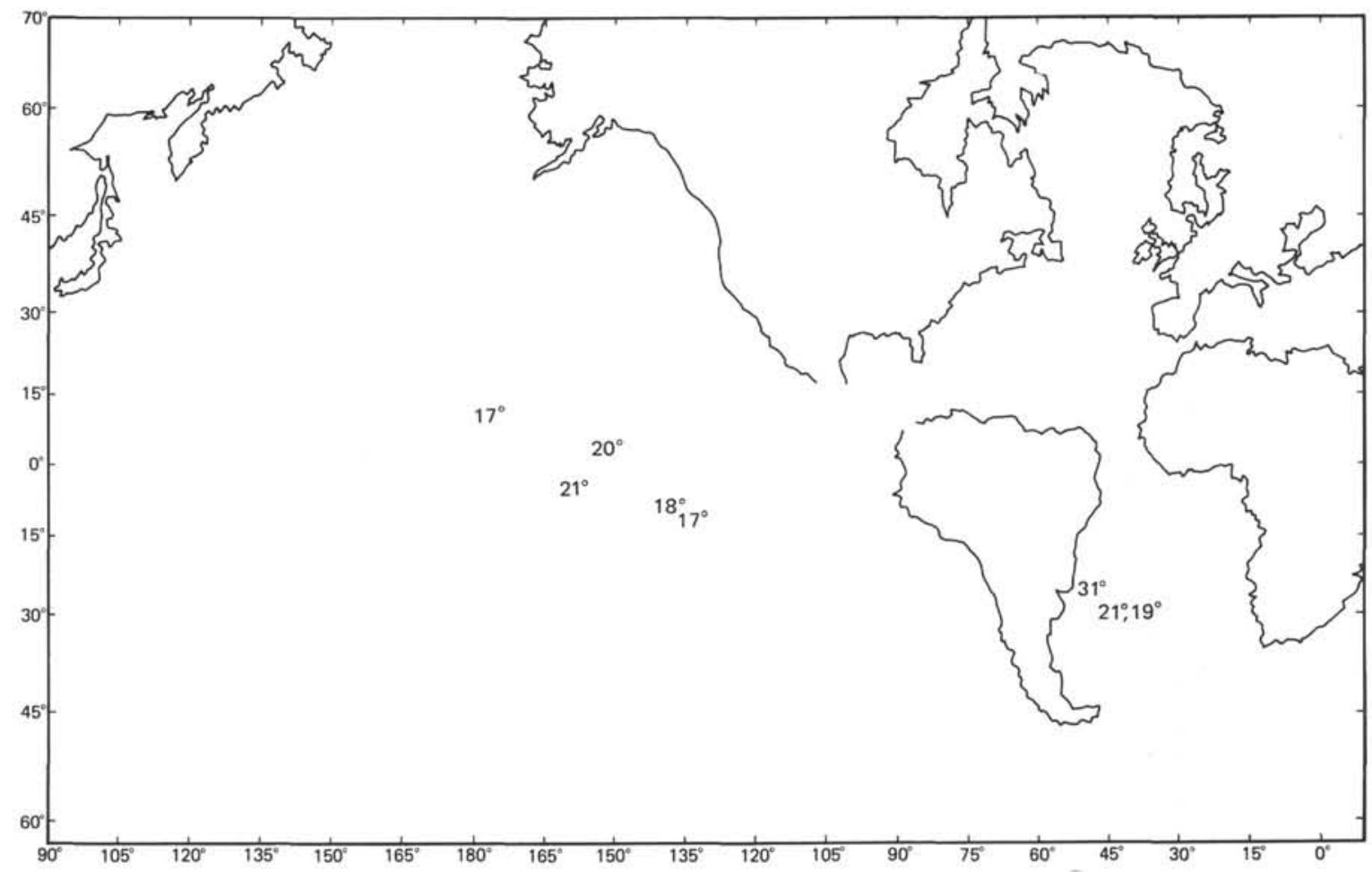

Figure 6. Plots of near-surface estimated paleotemperature values from planktonic microfossils of late Campanian age in the Pacific and Atlantic Oceans. Data are taken from Boersma and Shackleton (in press, and unpublished), Douglas and Savin (1971, 1973), Margolis et al. (1977), and Saito and Van Donk (1974). 


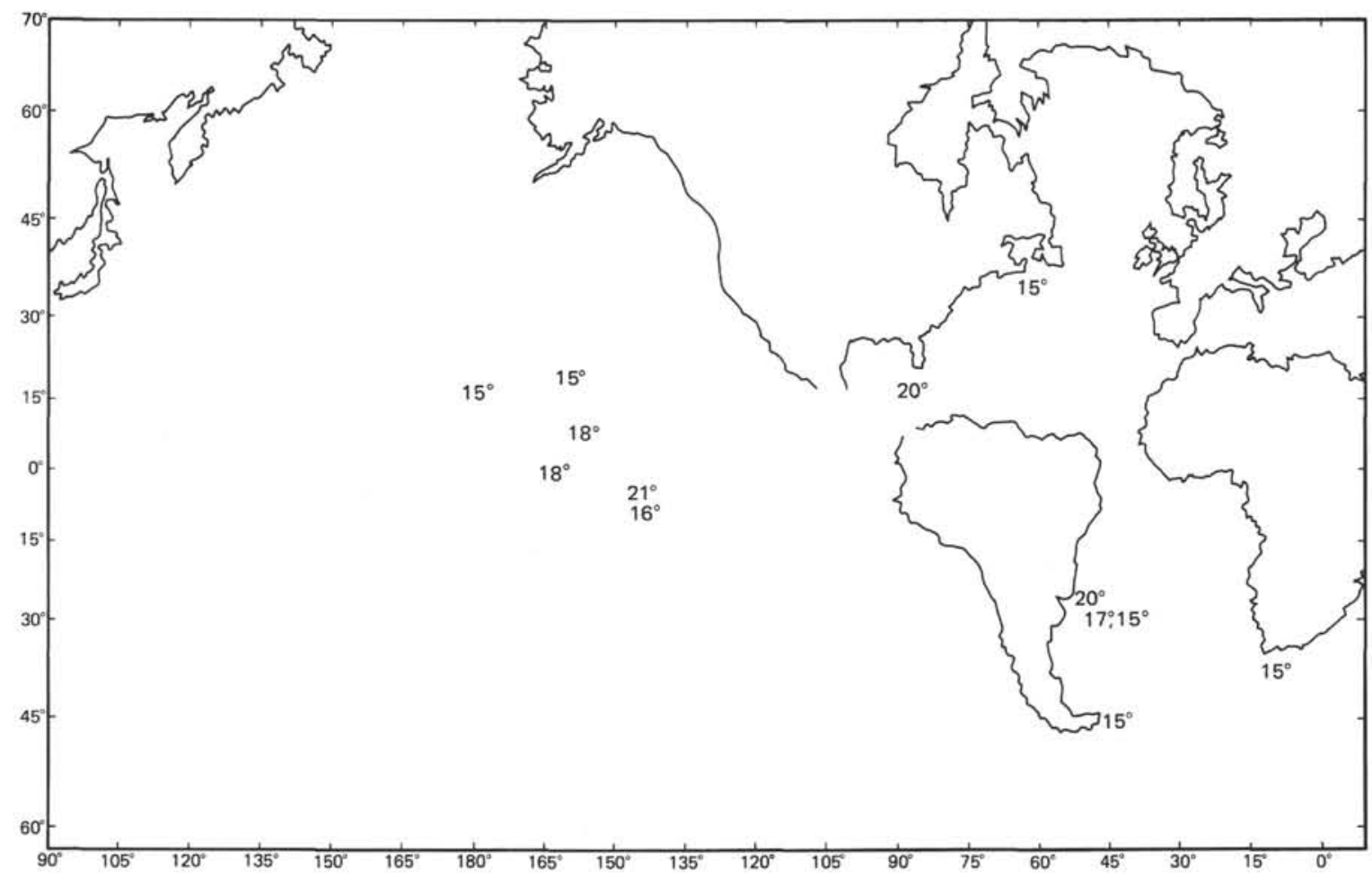

Figure 7. Late Maastrichtian estimated near surface temperatures in the Atlantic and Pacific oceans based on planktonic microfossils. Data is taken from Boersma and Shackleton (unpublished), Douglas and Savin $(1971,1973)$ and Satio and Van Donk (1974).

species, (2) In multiple analyses some species deviate markedly from a relatively consistent ordering according to carbon-isotope values.

In a thanatocenose, solution-resistant species are favored and solution-reprecipitation alteration of isotope values of preserved species biased by the isotopic ratios of lost species. In the Recent, solution-susceptible species are the most oxygen-isotope-negative species; hence, dissolved faunas tend to contain only isotopically heavier species. However, addition of isotopically lighter carbonate through recrystallization could lighten the values of the heavier species. In Late Cretaceous faunas, solution-resistant taxa include the isotopically lightest species Pseudoguembelina excolata and $P$. costulata, as well as the generally isotopically heavier globotruncanids (Sliter, 1971; Douglas, 1971; Caron, 1975). Solution-susceptible species such as Globigerinelloides spp., non-keeled juveniles, smooth heterohelicids, and $H$. globulosa include both isotopically light and heavy forms. Considering the very small oxygen-isotope range measured at any site to date, the re-equilibration effect must be small, unless there is exposure to substantially younger materials.

Results of several representative stratification arrays of planktonic foraminifers are shown in Table 7 and Figures 8 and 9. Stratification of Late Cretaceous planktonic foraminifers is shown in Table 8 . While hardly exhaustive, our analyses suggest that adults of ornamented Pseudoguembelina, Rugoglobigerina, striate Heterohelix, and Gtr. contusa lived at warmest temperatures. At slightly lower temperatures, the rugotrun- canids, Pseudotextularia, the single- and double-keeled globotruncanids, Planoglobulina glabrata, Racemiguembelina, and Abathomphalus occur. Deepest-dwelling genera include most smooth Heterohelix, Gublerina, the hedbergellids, and Shackoina.

Forms with fluctuating isotope values include species of Globigerinelloides, Gtr. citae, and R. fructicosa, which may be deviating from oxygen-isotope equilibrium, experiencing post-mortem isotopic alteration, or having greater size-dependent fractionation.

Figures 8 and 9 show Maastrichtian and Campanian planktonic-foraminifer arrays from Atlantic Sites 384 and 356 and Pacific Sites 465 and 463, plotted against estimated paleotemperature values. Planktonic foraminifers cluster together through very small thermal ranges. At times of higher estimated temperatures (when Pseudoguembelina or Rugoglobigerina have more-negative oxygen-isotope ratios), planktonic foraminifers are spread out through a slightly greater range of values. However, spread among Cretaceous planktonics measured to date has not exceeded $4^{\circ} \mathrm{C}$.

If the small spread in oxygen-isotope values among planktonics is not an artifact of diagenesis, then we conclude that many Cretaceous species are living at identical temperatures, and that some factor other than temperature must account for niche differentiation among these species.

\section{SUMMARY}

Oxygen- and carbon-isotope analyses were made on planktonic and benthic foraminifers from the Late Cre- 
Table 7. Oxygen-isotope values and related estimated temperatures for arrays of Cretaceous planktonic foraminifers from the Pacific and Atlantic Oceans. Species are ordered according to their oxygen-isotope values.

\begin{tabular}{|c|c|c|c|}
\hline Site/Level & Species & $\delta^{18} \mathrm{O}$ & $\begin{array}{c}\text { Estimated Temperature } \\
\left({ }^{\circ} \mathrm{C}\right)\end{array}$ \\
\hline \multirow[t]{7}{*}{$465 \mathrm{~A}-18-1,40 \mathrm{~cm}$} & Psg. costulata & $-1,81$ & 20 \\
\hline & $R$, rugosa & -1.69 & 19 \\
\hline & $P$. elegans & -1.60 & 19 \\
\hline & Gtr, calcarata & -1.27 & 17 \\
\hline & Gtr, subspinosa & -1.25 & 17 \\
\hline & Gtr. elevata & -1.16 & 17 \\
\hline & N. truempyi & -0.33 & 13 \\
\hline \multirow[t]{5}{*}{$463-21-9,14 \mathrm{~cm}$} & Psg. costulata & -2.09 & 21 \\
\hline & Gtr. calcarata & -1.46 & 18 \\
\hline & Gtr. elevata & -1.43 & 18 \\
\hline & Gtr. subspinosa & -1.31 & 18 \\
\hline & Benthics & -0.19 & 12 \\
\hline \multirow[t]{12}{*}{$356-29, \mathrm{CC}$} & Psg. excolata & -2.21 & 21 \\
\hline & Gtr. contusa & -2.21 & 21 \\
\hline & R. rugosa & -2.20 & 21 \\
\hline & R. fructicosa & -2.17 & 21 \\
\hline & H. navarroensis & -2.10 & 21 \\
\hline & Gtr. arca & -1.99 & 20 \\
\hline & H. monmouthensis & -1.98 & 20 \\
\hline & P. elegans & -1.95 & 20 \\
\hline & G. prairiehillensis & -1.89 & 20 \\
\hline & H. globulosa & -1.88 & 20 \\
\hline & Gtr. citae & -1.61 & 19 \\
\hline & P. glabrata & -1.28 & 17 \\
\hline \multirow[t]{11}{*}{$384-13-4,115 \mathrm{~cm}$} & R. rotundata & -0.93 & 16 \\
\hline & Psg. excolata & -0.72 & 15 \\
\hline & $P$. elegans & -0.54 & 14 \\
\hline & P. glabrata & -0.52 & 14 \\
\hline & H. pulchra & -0.48 & 14 \\
\hline & Gtr. stuartiformis & -0.46 & 14 \\
\hline & Gtr. contusa & -0.44 & 14 \\
\hline & Gtr. contusa & -0.36 & 13 \\
\hline & R. fructicosa & -0.11 & 13 \\
\hline & P. multicamerata & -0.05 & 12 \\
\hline & G. beccariformis & +0.52 & 10 \\
\hline \multirow[t]{15}{*}{$384-13-3,141 \mathrm{~cm}$} & R. rotundata & -0.82 & 15 \\
\hline & P. elegans & -0.77 & 15 \\
\hline & Gtr. contusa & -0.61 & 15 \\
\hline & H. striata & -0.58 & 14 \\
\hline & Gtr. gansseri & -0.52 & 14 \\
\hline & Gtr. stuartiformis & -0.50 & 14 \\
\hline & Psg. excolata & -0.46 & 14 \\
\hline & P. multicamerata & -0.46 & 14 \\
\hline & R. fructicosa & -0.34 & 13 \\
\hline & A. mayaroensis & -0.25 & 13 \\
\hline & P. glabrata & -0.16 & 13 \\
\hline & Gtr. arca & -0.09 & 12 \\
\hline & Gtr. citae & -0.07 & 12 \\
\hline & H. pulchra & -0.02 & 12 \\
\hline & Benthics & +0.73 & 9 \\
\hline \multirow[t]{18}{*}{$384-13-3,57 \mathrm{~cm}$} & Psg. excolata & -0.87 & 15 \\
\hline & Gtr. contusa & -0.72 & 15 \\
\hline & R. rotundata & -0.68 & 15 \\
\hline & P. elegans & -0.60 & 15 \\
\hline & Gtr. arca & -0.61 & 15 \\
\hline & H. striata & -0.60 & 15 \\
\hline & P. glabrata & -0.59 & 14 \\
\hline & R. rugosa & -0.54 & 14 \\
\hline & R. fructicosa & -0.43 & 14 \\
\hline & A. mayaroensis & -0.43 & 14 \\
\hline & Gtr. stuartiformis & -0.33 & 13 \\
\hline & Gtr. citae & -0.35 & 13 \\
\hline & H. globulosa & -0.34 & 13 \\
\hline & Gublerina sp. & -0.38 & 13 \\
\hline & H. prairiehillensis & -0.32 & 13 \\
\hline & H. monmouthensis & -0.17 & 13 \\
\hline & H. pulchra & +0.27 & 11 \\
\hline & Benthics & +1.05 & 8 \\
\hline \multirow[t]{6}{*}{$152-15-2,86 \mathrm{~cm}$} & Psg. excolata & -1.91 & 20 \\
\hline & R. subcircumnodifer & -1.65 & 19 \\
\hline & Gtr. contusa & -1.55 & 19 \\
\hline & Gtr, stuartiformis & -1.25 & 17 \\
\hline & R. rotundata & -1.06 & 16 \\
\hline & Benthics & -0.02 & 12 \\
\hline
\end{tabular}

taceous and earliest Tertiary of DSDP Sites 463 and 465 in the central Pacific. Estimated paleotemperature records demonstrate Late Cretaceous temperature maxima in the mid-Turonian to Coniacian, and late Campanian. The temperature minimum occurred in the early Maastrichtian. There is a slight drop in near-surface paleotemperatures across the Cretaceous/Tertiary boundary at Site 465 .

Bottom temperatures generally parallel surface values; however, there is a slight warming of bottom temperatures through the course of the Maastrichtian, a characteristic cool excursion just before the Cretaceous/ Tertiary boundary, and no apparent temperature variation across the Cretaceous/Tertiary boundary.

Carbon-isotope gradients through the water column are slightly lower in the Coniacian, but average near $1.5 \%$ through the Late Cretaceous.

There is a major negative excursion in carbon-isotope values across the Cretaceous/Tertiary boundary. The near-zero carbon-isotope gradient of the early Paleocene is $1.5 \%$ less than in the latest Cretaceous; these values continue through the "'G.' eugubina Zone. A negligible gradient suggests a time of reduction in utilization of available inorganic carbon in the "'G." eugubina Zone. The very low productivity of this time is the reflection of the Cretaceous/Tertiary boundary catastrophe, which we believe occurred on a time scale below our ability to detect with isotope analysis.

Paleolatitudinal reconstructions locate Sites 463 and 465 in the subtropics in the late Campanian to late Maastrichtian. Plots of all available Atlantic and Pacific oxygen-isotope data for these times demonstrate equivalent temperatures in the equatorial Pacific, $\mathrm{Ca}$ ribbean, and middle-latitude South Atlantic. Meridional temperature gradients from the equator to middle latitudes equal only $5^{\circ} \mathrm{C}$. East-west paleotemperature gradients in the South Atlantic also reach $5^{\circ} \mathrm{C}$.

Analysis of depth habitats of Late Cretaceous planktonic foraminifers in the Pacific and Atlantic demonstrates that the forms living at warmest temperatures were adults of Psg. costulata, Psg. excolata, $R$. rotundata, $R$. rugosa, P. elegans, H. striata, and Gtr. contusa. Slightly lower temperatures were occupied by the rugotruncanids, and all other globotruncanids, including Gtr. fornicata, Abathomphalus, Racemiguembelina; and Planoglobulina glabrata. Coolest temperatures were indicated by the hedbergellids, Gublerina, smooth Heterohelix species, Shackoina, and Planoglobulina multicamerata.

Planktonic foraminifers, if their values are not artifacts of diagenesis, cluster together through only a $4^{\circ} \mathrm{C}$ temperature range. Factors other than temperature must be determining the niche partitioning of these species.

\section{ACKNOWLEDGMENTS}

We would like to express our gratitude to DSDP for allowing the senior author to participate in Leg 62. Special thanks are extended to Tracy Vallier for his successful effort to recover the Cretaceous/Tertiary boundary at Site 465 . We thank Bill Hochhausen, Barbara Taylor, Mike Brown and draftspersons at DSDP for help with the figures. Mike Hall is to be congratulated for his continuing "mastery of the micromass.' 
465A-18-1, $40 \mathrm{~cm}$

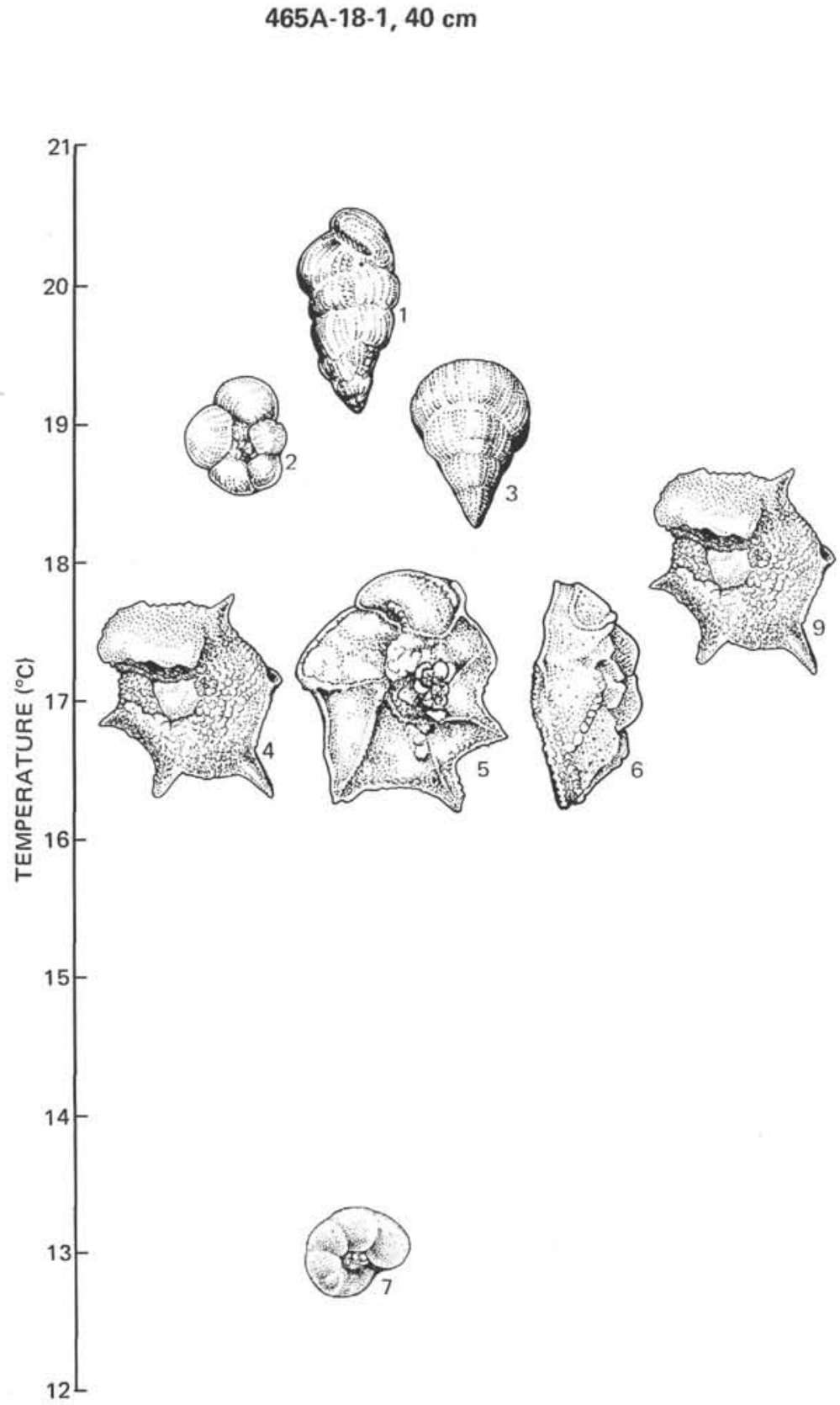

$463-21-4,14 \mathrm{~cm}$
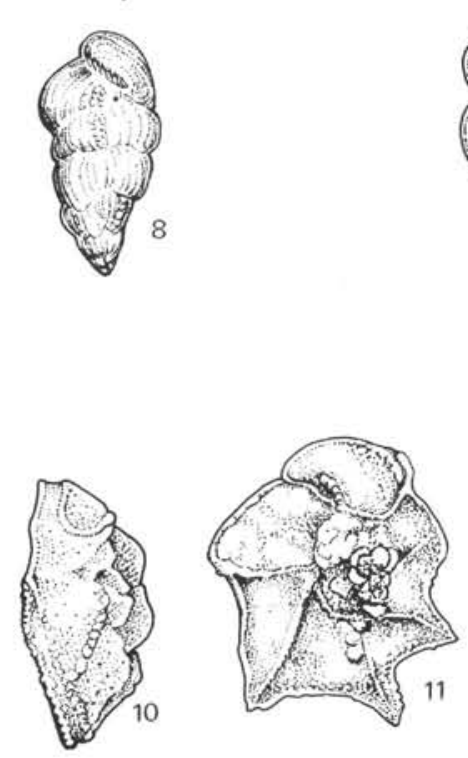

356-29, CC
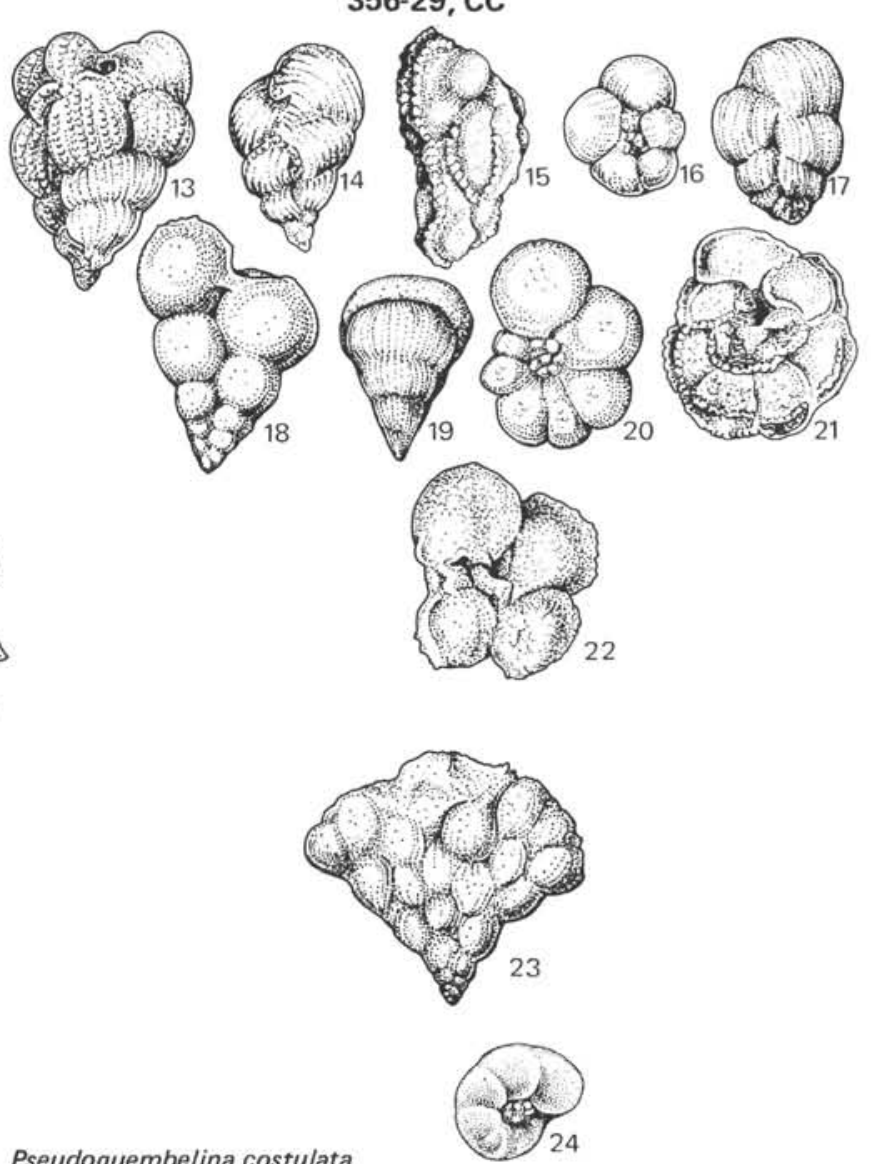

Pseudoguembelina costulat

Rugoglobigerina rugosa

Pseudotextularia elegans

Globotruncana calcarata

Globotruncana subspinosa

Globotruncana subsinos

6,10 Globotruncana elevata

$7,12,24$ Benthic foraminifera
$13 \quad$ Racemiguembelina fructicosa

13 Pacemiguembelina fructicosa

14 Pseudoguembelina excola
15 Globotruncana contusa

17 Heterohelix navarroensis

18 Heterohelix globulosa

20 Globigerinelloides $s p$.

21 Globotruncana arca

22 Globotruncana citae
23 Planoglobulina glabrata

Figure 8. Stratification arrays of selected late Maastrichtian and late Campanian planktonic foraminifers according to their estimated paleotemperatures at Sites 465 and 463 (late Campanian) and Site 356 late Mastrichtian) in the South Atlantic. Fossils are listed in Tables 6 and 7. 


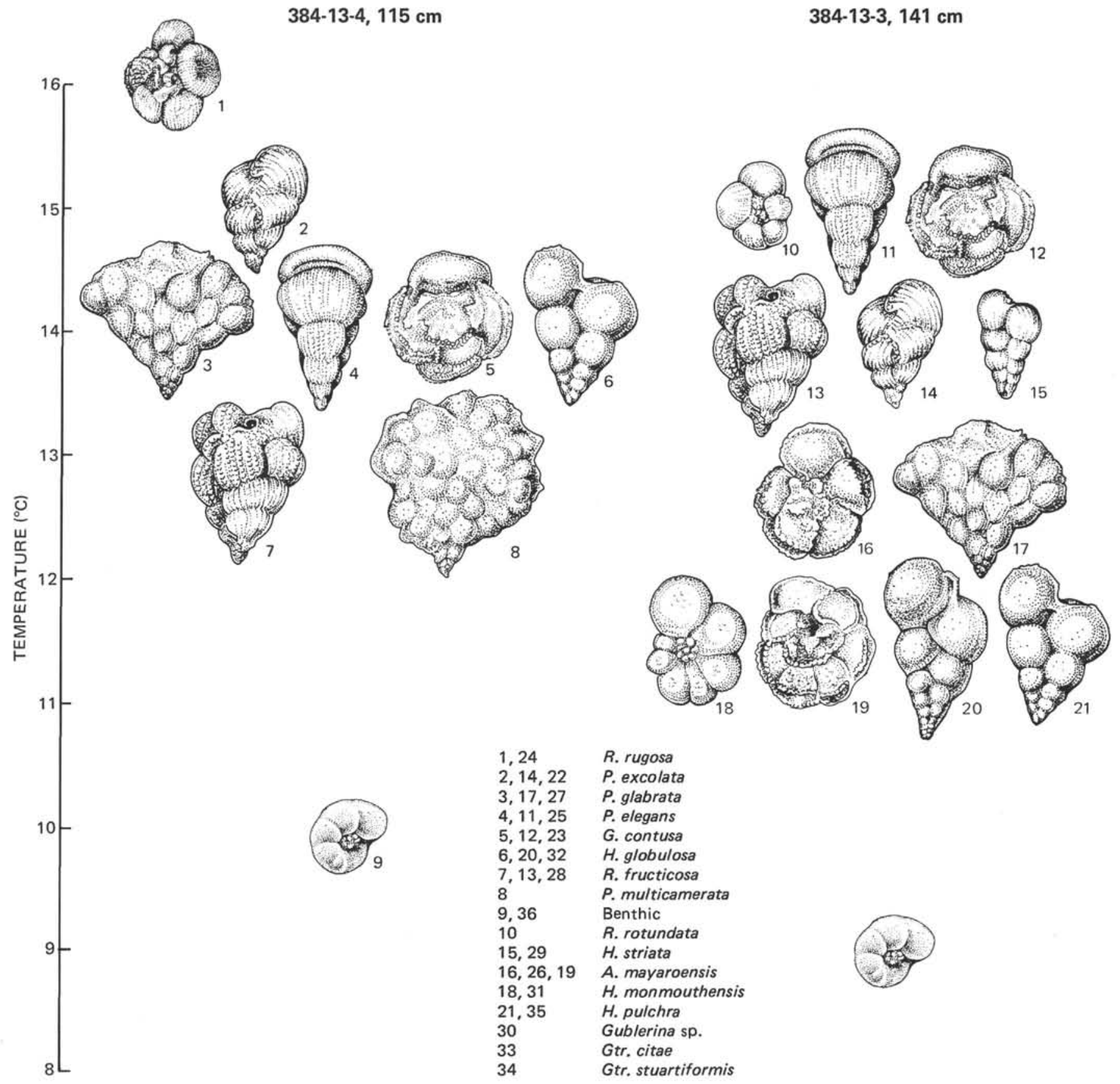

Figure 9. Stratification arrays of selected late Maastrichtian planktonic foraminifera from DSDP Site 384 in the North Atlatic. Species are listed in Table 7 . Fossils are stratified only through a $4^{\circ} \mathrm{C}$ temperature range at this site.

This research was supported by NSF grants OCE-76-83000, OCE-79-20101, and a NERC grant to N. J. Shackleton.

\section{REFERENCES}

Boersma, A., and Shackleton, N. J., 1977. Tertiary oxygen and carbon isotope stratigraphy, Site 357 (mid latitude South Atlantic). In Supko, P. R., Perch-Nielsen, K., et al., Init. Repts. DSDP, 39: Washington (U.S. Govt. Printing Office), 911-924.

1979. Carbon and oxygen isotope records at DSDP Site 384 (North Atlantic) and some Paleocene paleotemperatures and carbon isotope variations in the Atlantic Ocean. In Tucholke, B. E., Vogt, P. R., et al., Init. Repts. DSDP, 43: Washington (U.S. Govt. Printing Office), 695-717.
, in press. Oxygen and carbon isotope variations across the Cretaceous/Tertiary boundary in the Atlantic Ocean. In Berggren, W. A., and Van Couvering, J. (Eds.), Symposium on Catastrophes: Princeton (Princeton Univ. Press).

Broecker, W. S., 1974. Chemical Oceanography: New York (Harcourt Brace Jovanovitch).

Caron, M., 1975. Late Cretaceous planktonic foraminifera from the northwest Pacific, Leg 32 of the Deep Sea Drilling Project. In Larson, R. L., Moberly, R., et al., Init. Repts. DSDP, 32: Washington (U.S. Govt. Printing Office), 710-724.

Douglas, R. G., 1971. Cretaceous foraminifera from the northwest Pacific Ocean: Leg 6, Deep Sea Drilling Project. In Fischer, A. G. Heezen, B. C., et al., Init. Repts. DSDP, 6: Washington (U.S. Govt. Printing Office), 1027-1053. 


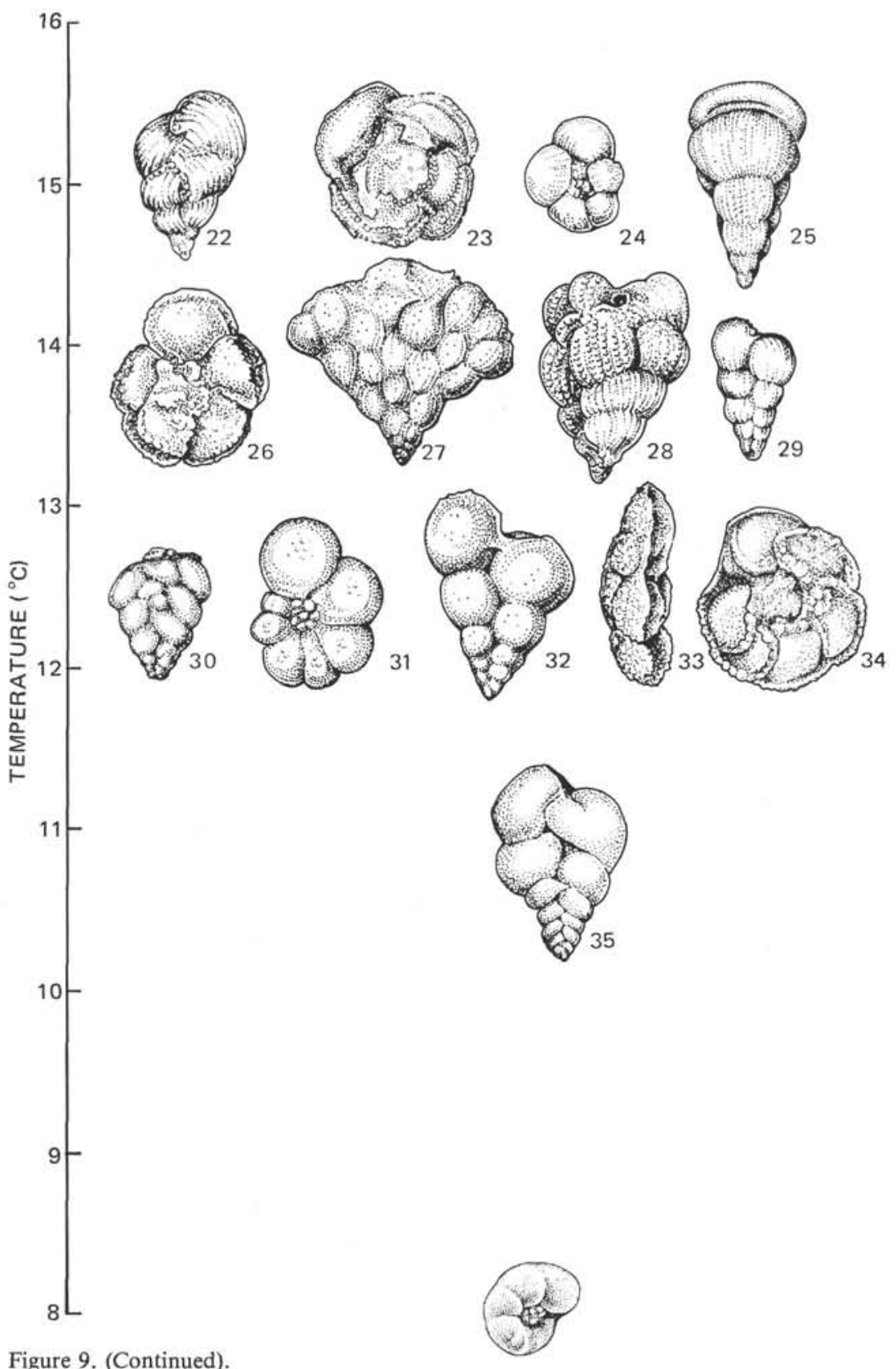

Douglas, R. G., and Savin, S., 1971. Isotopic analyses of planktonic foraminifera from the Cenozoic of the northwest Pacific, Leg 6. In Fischer, A. G., Heezen, B. C., et al., Init. Repts. DSDP, 6: Washington (U.S. Govt. Printing Office), 1123-1127.

1973. Oxygen and carbon isotope analyses of Cretaceous and Tertiary foraminifera from central North Pacific. In Winterer, E. L., Ewing, J. I., et al., Init. Repts. DSDP, 17: Washington (U.S. Govt. Printing Office), 591-605.

,1975. Oxygen and carbon isotope analyses of Tertiary and Cretaceous microfossils from Shatsky Rise and other sites in the North Pacific Ocean. In Larson, R. L., Moberly, R., et al., Init. Repts. DSDP, 32: Washington (U.S. Govt. Printing Office), 509-521.

Douglas, R. G., and Sliter, W. V., 1966. Regional distribution of some Cretaceous Rotaliporidae and Globotruncanidae (Foraminiferida) within North America. Tulane Stud. Geol., 4:89-131.

Kroopnick, P. S., Margolis, P., and Wong, C. S., 1979. ${ }^{13} \mathrm{C}$ variations in marine carbonate sediments as indicators of the $\mathrm{CO}_{2}$ balance between the atmosphere and the oceans. In Anderson, N. R., and Malahoff, A. (Eds.), The Fate of Fossil Fuel $\mathrm{CO}_{2}$ in the Oceans: New York (Plenum), pp. 295-322.

Lancelot, Y., and Larson, R., 1975. Sedimentary and tectonic evolution of the northwestern Pacific. In Larson, R. L., Moberly, R., et al., Init. Repts. DSDP, 32: Washington (U.S. Govt. Printing Office), 925-941.

Margolis, P., Kroopnick, P. S., and Goodney, D., 1977. Cenozoic and late Mesozoic paleooceanographic and paleoglacial history recorded in circum-Antarctic deep sea sediments. Mar. Geol., 25:131-147.

Premoli-Silva, I., and Bolli, H. M., 1975. Late Cretaceous to Eocene planktonic foraminifera and stratigraphy of Leg 15 sites in the Caribbean Sea. In Edgar, N. T., Saunders, J. B., et al., Init. 
Repts. DSDP, 15: Washington (U.S. Govt. Printing Office), 499-544.

Saito, T., and Van Donk, J., 1974. Oxygen and carbon isotope measurements of late Cretaceous and early Tertiary foraminifera. Micropaleont., 20:152-177.

Savin, S., 1977. The history of the earth's temperature during the past 100 million years. Ann. Rev. Earth Planet. Sci., 5:319-355.

Shackleton, N. J., and Opdyke, N. D., 1974. Oxygen isotope and paleomagnetic stratigraphy of equatorial Pacific Core V28-238: oxygen isotope temperatures and ice volume on a $10^{5}$ and $10^{6}$ year scale. Quat. Res., 3:39-55.

Sliter, W. V., 1976. Cretaceous foraminifers from the southwestern Atlantic Ocean, Leg 36, Deep Sea Drilling Project. In Barker, P. F., Dalziel, I. W. D., et al., Init. Repts. DSDP, 36: Washington (U.S. Govt. Printing Office), 510-545.

Spaeth, C., Hoefs, J., and Vetter, U., 1971. Some aspects of isotopic composition of belemnites and related paleotemperatures. Geol. Soc. Am. Bull., 82:3139-3150.

Stevens, G. R., and Clayton, R. N., 1971. Oxygen isotope studies on Jurassic and Cretaceous belemnites from New Zealand and their biogeographic significance. New Zealand J. Geol. Geophys., 14:829-897.

Thierstein, H. R., and Berger, W. H., 1978. Injection events in ocean history. Nature, 276:461-466.

van Hinfe, J., 1976. A Cretaceous time-scale. Bull. Am. Assoc. Petrol. Geol., 60:498-516.
Table 8. Stratification order of late Cretaceous planktonic foraminifers according to their oxygen-isotope values.

\begin{tabular}{ll}
\hline Oxygen-Isotope Ratios & \multicolumn{1}{c}{ Species } \\
\hline & Pseudoguembelina excolata \\
& P. costulata \\
& Rugoglobigerina rotundata \\
Lightest isotope values & Rugoglobigerina rugosa \\
& Heterohelix striata \\
& Rugotruncana subcircumnodifer \\
& Globotruncana contusa \\
& Gtr. fornicata \\
& Pseudotetularia elegans \\
& Rugotruncana cretacea \\
& All other globotruncanids \\
& Planoglobulina glabrata \\
Intermediate isotope values & Racemiguembelina fructicosa \\
& Abathomphalus mayaroensis \\
& Globigerinelloides spp. \\
& Heterohelix globulosa \\
& Heterohelix pulchra \\
& Gublerina sp. \\
Heaviest isotope values & Planoglobulina multicamerata \\
& Hedbergella spp. \\
& Shackoina \\
& "G." citae
\end{tabular}

